\title{
THE ROLE OF NON-GOVERNMENTAL ORGANIZATION IN SANITATION VILLAGE PROGRAM IN SEMANGGI VILLAGE, SURAKARTA
}

\author{
Anak Agung Alit Kirti Estuti Narendra Putri ${ }^{1)}$, Hermanu Joebagioº), \\ Dono Indarto3) \\ 1)Masters Program in Public Health, Sebelas Maret University \\ 2)Faculty of Teaching and Educational Sciences, Sebelas Maret University \\ 3)Department of Physiology, Faculty of Medicine, Sebelas Maret University
}

\begin{abstract}
Background: Sanitation Village Program is one of notable community-based water supply and sanitation development models in Indonesia. A NonGovernmental Organization (NGO) namely Community Self-Reliant Group had been established in Semanggi Village Surakarta, to manage Sanitation Village Program. This study aimed to examine the role of non-governmental organization in sanitation village program in Semanggi Village, Surakarta.

Subjects and Method: This was an analytical qualitative study with phenomenology approach. The study was carried out in Semanggi Village, Surakarta, Central Java, in June 2017. The informants were selected consisting of 12 community members and 3 community leaders. The data were collected by in-depth interview and focus group discussion. The data were analyze using content analysis.

Results: A Community Self-Reliant Group had been established in Semanggi Village, Surakarta, to manage Sanitation Village Program. This group had the responsibility to manage maintenance of water and sanitation facilities, including checking septic communal tanks, checking water facilities and latrines at resident houses, as well as repairing damaged water and sanitation facilities. In addition, the Community Self-Reliant Group had a financial management responsibility role, including financial accounting of sanitation maintenance costs. The group also acted as communication intermediary between community member, community leaders, and external agents such as Public Agency of Water Supply, to solve water and sanitation-related problems.

Conclusion: Community Self-Reliant Group has an important role in managing various maintenance activities of water and sanitation facilities, including checking septic communal tanks, checking water facilities and latrines at resident houses, as well as repairing damaged water and sanitation facilities. Community Self-Reliant Group can serve as a role model of community empowerment in achieving populations health.
\end{abstract}

Keywords: community self-reliant group, sanitation village program, environmental health

Correspondence: Anak Agung Alit Kirti Estuti Narendra Putri. Masters Program in Public Health, Sebelas Maret University, Jl. Ir. Sutami 36A, Surakarta, Central Java. Email: kirtiestuti@gmail.com.

Mobile: +6285643231616 